Tersedia online di: http://ejournal-balitbang.kkp.go.id/index.php/JP
e-mail:jurnalpari@gmail.com
JURNAL PARI
volume 4 Nomor 1 Juli 2018
p-ISSN: 2502-0730
e-ISSN : 2549-0133

\title{
KURANGNYA PEMAHAMAN APARATUR SIPIL NEGARA TERHADAP PENANGANAN KEARSIPAN YANG BAIK PADA UNIT PELAKSANA TEKNIS SEKOLAH USAHA PERIKANAN MENENGAH SORONG LINGKUP KEMENTERIAN KELAUTAN DAN PERIKANAN
}

\author{
ARFAFAKAUBUN \\ Sekolah Usaha Perikanan Menengah Sorong \\ Diterima tanggal : 15 Februari 2018 Diterima setelah perbaikan : 17 Mei 2018 \\ disetujui terbit : 29 Juni 2017
}

\begin{abstract}
ABSTRAK
Sesuai Amanat Undang-Undang Nomor 5 Tahun 2014 tentang Aparatur Sipil Negara dan Undang-Undang Nomor 43 Tahun 2009 tentang Kearsipan. Untuk mempertahankan Negara Kesatuan Republik Indonesia sebagaimana tercantum dalam Pembukaan Undang-Undang Dasar Negara Republik Indonesia 1945 yaitu kearsipan sebagai identitas dan jati diri bangsa, dan bahan pertanggung jawaban dalam kehidupan bermasyarakat, berbangsa dan bernegara, sehingga perlu dikelola dan diselamatkan oleh negara. untuk menjamin ketersediaan arsip yang autentik dan terpercaya. maka perlu adanya perlindungan terhadap hak-hak keperdataan rakyat. sistem kearsipan diperluhkan penyelenggaraan kearsipan yang sesuai dengan prinsip kaidah dan standar kearsipan yang sebagaimana dibutuhkan oleh suatau sistem penyelenggaraan kearsipan yang andal, serta meningkatkan kualitas pelayanan publik di lembaga negara, pemerintah, organisasi politik, organisasi kemasyarakatan maupun perorangan, sehinnga harus dilakukan dalam suatu sistem penyelenggaraan kearsipan nasional yang komprehensif dan terpadu. Sesuai amanat undang-undang tersebut, maka seharusnya pegawai Sekolah Usaha Perikanan Menengah Sorong sebagai Aparatur Sipil Negera tentuh sudah perlu memahami dan wajib menjalankan, karena kearsipan bagi sebuah intsansi pemerintah maupun suatu organisasi masyarakat sangatlah penting karena kata kunci kearsipan sebagai alat bukti yang sah, dan sebagai simpul pemersatu bangsa dan negara.
\end{abstract}

Kata Kunci : Kearsipan sebagai simpul pemersatu bangsa dan negara.

\begin{abstract}
In accordance with the mandate of Law Number 5 of 2014 concerning State Civil Apparatus and Law Number 43 of 2009 concerning Archives. To defend the Unitary State of the Republic of Indonesia as stated in the Preamble to the 1945 Constitution of the Republic of Indonesia, namely archival as national identity and identity, and accountability material in the life of society, nation and state, so that it needs to be managed and saved by the state. to ensure the availability of authentic and reliable archives. it is necessary to protect the civil rights of the people. the archival system is required to carry out archives in accordance with the principles of archival standards and standards as required by a reliable archival system, and improve the quality of public services in state institutions, governments, political organizations, community organizations and individuals, so it must be carried out in an implementation system comprehensive and integrated national archives. In accordance with the mandate of the law, the employees of the Sorong Intermediate Fisheries School as Civil Servants must have understood and are obliged to run, because filing for a government agency and a community organization is very important because archival keywords are valid evidence, and as a unifying node of the nation and state.
\end{abstract}

Keywords : Archives as a unifying node of the nation and state. 


\section{PENDAHULUAN}

Dalam menghadapi tantangan globalisasi dan mendukung terwujudnya penyelenggaraan negara dan khususnya pemerintahan yang baik dan bersih, serta peningkatan kualiatas pelayanan publik, pelayanan kearsipan di lembaga negara, pemerintahan, lembaga pendidikan, perusahaan, organisasi politik, organisasi kemasyarakatan dan perseorangan harus dilakukan dalam suatu sistem penyelenggaraan kearsipan nasional yang komprehensif dan terpadu.

Adapun dalam rangka mempertahankan Negara Kesatuan Republik Indonesia dan mencapai cita-cita nasional sebagaimana tercantum dalam Pembukaan Undang-Undang Dasar Negara Republik Indonesia Tahun 1945 bahwa arsip sebagai identitas dan jati diri bangsa, serta sebagai memori, acuan dan bahan pertanggungjawaban dalam kehidupan bermasyarakat, berbangsa dan bernegara sehingga harus dikelola dan diselamatkan oleh negara.

Untuk menjamin ketersediaan arsip yang autentik dan terpercaya, menjamin perlindungan kepentingan negara dan hak-hak keperdataan rakyat, serta mendinamiskan sistem kearsipan yang sesuai dengan prinsip, kaidah dan standar kearsipan sebagaimana dibutuhkan oleh suatu sistem penyelenggaraan kearsipan nasional yang andal.

Mengelola Kearsipan harus berpedoman pada Tata Naskah Dinas, dan Sekolah Usaha Perikanan Menengah Sorong di bawah naungan Kementerian Kelautan dan Perikanan dan lingkup Badan Riset dan Sumber Daya Manusia Kelautan dan Perikanan, maka Kearsipan dan Tata Naskah Dinas berpedoman pada Peraturan Menteri Kelautan dan Perikanan Nomor 53/ PERMEN-KP/2014 tentang Kearsipan dan Peraturan Menteri Kelautan dan Perikanan Nomor 52/PERMENKP/2014 tentang Pedoman Umum Tata Naskah Dinas serta Peraturan Kepala Badan Riset dan Sumber Daya Manusia Kelautan dan Perikanan Nomor 7/PERBRSDM-KP/2017 tentang Petunjuk Pelaksanaan Tata Naskah Dinas Lingkup Badan Riset dan Sumber Daya Manusia Kelautan dan Perikanan.

Sesuai amanat undang-undang kearsipan nomor 43 Tahun 2009, dimana seharusnah dan sudah sepantasnya Aparatur Sipil Negara harus memahami dan mengerti tentang tujuan, manfaat dan kegunaan kearsipan pada instansi pemerintah maupun suatu organisasi atau individu, karena kearsipan itu sangatlah penting dan janganlah dilihat karena sepucuk kertas yang pasti akan rusak atau tersobek, tapi perlu di pahami bahwa sepucuk kertas itulah yang akan membantu kita dalam menyelesaikan suatu masalah baik itu masalah yang berhubungan dengan Korupsi Kolusi dan Nepotisme (KKN), batas wilayah teritorial sebuah negara, batas wilayah kota, kabupaten, provinsi maupun negara dll, oleh karena itu kita sebagai Aparatur Sipil Negara pada Sekolah Usaha Perikanan Menengah Sorong lingkup Kementerian Kelautan dan Perikanan, harus pandai menjalankan tugas sebagai abdi negara dan abdi masyarakat yang efektif dan efisiens.

Walaupun kita sebagai Tenaga Pendidik maupun Tenaga Kependidikan pada Sekolah Usaha Perikanan Menengah Sorong tapi perlu diingat bahwa kita bekerja yang berhubungan dengan administrasi yang namanya kearsipan yaitu kearsipan Keuangan, Kepegawaian, Tata Usaha, Pengajaran, Kesiswaan, Sarana dan Prasarana Pendidikan (SARDIK) dan Hubungan Masyarakat (HUMAS), oleh karena itu kita harus memandang kearsipan itu sebagai sesuatu yang berharga bukan memandang dengan sebelah mata artinya kita harus berprinsip bahwa sewaktu-waktu ada yang memerluhkan arsip kita baik itu untuk persyaratan kenaikan pangkat, permintaan data peserta didik atau alumni, tes peserta didik baru, pembuktian pada saat pemeriksaan dokumen kapal, keuangan negara dll.

Sehubungan dengan hal tersebut diatas kiranya tenaga Pendidik dan Tenaga Kependidikan pada Sekolah Usaha Perikanan Menengah Sorong sudah sepantasnya dan seharusnya menyadari bahwa kearsipan itu sangatlah penting bagi individu, instansi Pemerintah, maupun masayarak pada umumnya. karena bukan hanya dianggap surat itu sepucuk kertas tapi itu adalah dokumen yang sangat penting yang harus di jaga kerahasiannya dan dirawat sebaik mungking agar tidak menimbulkan kerugian dalam arti sobek atau rusak di makan rayap, bocor ke publik dokumen negara dll.

\section{TINJAUAN PUSTAKA}

Dalam Undang-Undang Nomor 34 Tahun 2009 tentang Kearsipan, dikatakan bahwa arsip adalah rekaman kegiatan atau peristiwa dalam berbagai bentuk dan media sesuai dengan perkembangan teknologi informasi dan komunikasi yang dibuat dan diterima oleh lembaga negara, pemerintahan, lembaga pendidikan, perusahaan, organisasi politik, organisasi kemasyarakatan dan berbangsa dan bernegara. Sedangkan Pedoman Tata Kearsipan, dalam kaitan dengan fungsi kearsipan yaitu mengelola naskah dinas yang dibuat dan diterima oleh setiap unit kerja dan mengelola setiap rekaman kegiatan atau peristiwa yang terjadi di lingkungan pemerintahan maupun organisasi atau lembaga lainnya. Maka kearsipan dikatakan sebagai hal-hal yang berkenaan dengan arsip/warkat. 
Secara umum arsip dapat didefinisikan secara sempit maupun secara luas, dalam pengertian sempit yang dimaksud dengan arsip adalah naskah dinas yang dibuat dan diterima pimpinan unit kerja dalam bentuk corak apapun baik dalam keadaan tunggal maupun kelompok dalam rangka pelaksanaan kegiatan pemerintah. Sementara dalam makna yang luas, arsip adalah rekaman kegiatan atau peristiwa dalam berbagai bentuk dan media sesuai dengan perkembangan teknologi informasi dan komunikasi yang dibuat dan diterima oleh lembaga negara, pemerintah, lembaga pendidikan dan organisasi kemasyarakatan.

Maka yang dimaksud dengan pengertian Kearsipan adalah Hal-hal yang berkenaan dengan arsip, yaitu arsip terdiri dari arsip statis dan arsip dinamis. Arsip dinamis meliputi arsip inaktif, arsip aktif. Ada juga arsip terjaga dan arsip umum, arsip terbuka, arsip tertutup, arsip asli, arsip tembusan, arsip salinan, arsip petikan, arsip keuangan, arsip kepegawaian, arsip pendidikan.

Dibawah ini ada beberapa pendapat para ahli mengenai defenisi Kearsipan adalah sebagai berikut :

1. Menurut Undang-Undang Nomor 43 Tahun 2009 tentang kearsipan adalah hal-hal yang berkenang dengan arsip yang perlu dijaga, dirawat karena sebagai jati diri bangsa dan sebagai alat bukti yang sah

2. Menurut The Liang Gie (2000) yaitu arsip sebagai kumpulan warkat-warkat yang disimpan secara teratur, berencana karena mempunyai sesuatu kegunaan agar setiap kali diperlukan dapat cepat ditemukan kembali

3. Menurut Drs. Ig. Wursanto (1989) kearsipan adalah proses kegiatan pengurusan atau pengaturan arsip dengan mempergunakan suatu sistem tertentu sehingga arsip-arsip dapat ditemukan kembali dengan mudah dan cepat apabila sewaktu-waktu diperlukan.

4. Menurut Maulana (1974) memberikan rumusan bahwa kearsipan adalah suatu metode atau cara yang direncanakan dan dipergunakan untuk menyimpan, pemeliharaan arsip bagi individu maupun umum dengan memakai indeks yang sudah ditentukan, biasanya untuk keperluan, filling ini dipergunakan lemari, laci cabinet dari bahan baja tahan karat atau dari kayu yang terkunci, jauh dari bahaya yang tidak diinginkan.

5. Menurut 3 penulis : Mulyono, Muhsin, dan Marimin (1985) memberikan pengertian tentang kearsipan yaitu tata cara pengurusan penyimpanan warkat menurut

6. aturan dan prosedur yang berlaku dengan mengingat tiga unsur pokok yang yakni penyimpanan, penempatan, dan penemuan kembali.

7. Menurut Wursanto (1991) Arsip adalah kumpulan warkat yang disimpan secara teratur berencana karena mempunyai suatu kegunaan agar setiap kali diperlukan dapat cepat ditemukan kembali.

Berdasarkan definisi beberapa ahli di atas, arsip merupakan kumpulan naskah-naskah atau dokumen dalam corak apapun (cd, peta, pita rekaman, piringan hitam, mikro film dll) yang di dalamnya memberikan keterangan- keterangan atau bukti tentang sutau kejadian, sehingga pada saat di perlukan dapat dengan mudah ditemukan. Arsip adalah naskah- naskah dinas yang dibuat dan diterima oleh semua satuan organiosasi dalam lingkungan Departemen dalam negeri dalam bentuk corak apapun, baik dalam keadaan tunggal maupun berkelompok dalam pelaksanaan tugas.

Wursanto (1991) membagi jenis arsip dilihat dari beberapa segi diantaranya :

1. Menurut subjek atau isisnya :

a. Arsip Keuangan Jenis arsip yang berhubungan dengan masalah keuangan seperti laporan keuangan, surat perintah membayar tunai, surat penagihan, dan daftar gaji.

b. Arsip Kepegawaian jenis arsip yang berhubungan dengan masalah kepegawaian seperti daftar riwayat hidup pegawai, surat keputusan kenaikan pangkat pegawai, kenaikan gaji berkala pegawai, daftar hadir pegawai (absensi) dll.

c. Arsip Pemasaran jenis arsip yang berhubungan dengan masalah-masalah pemasaran seperti surat penawaran, surat pesanan, daftar harga barang, surat permintaan kebutuhan barang.

d. Arsip Pendidikan jenis arsip yang berhubungan dengan masalah-masalah pendidikan seperti Perangkat Pembelajaran, Proses Belajar Mengajar (PBM), satuan pelajaran, program pengajaran, daftar absensi peserta didik dan tenaga pendidik.

\section{Arsip menurut bentuk dan wujudnya :}

a. Surat setiap lembaran kertas yang berisi informasi atau keterangan yang berguna bagi penyelenggara kehidupan organisasi seperti naskah perjanjian atau kontrak, akte pendirian perusahaan, notulen rapat, kuitansi, naskah berita acara, kartu pegawai.

b. Pita rekaman

c. Piringan hitam

d. Mikro film, film yang memuat rekaman bahan tertulis, tercetak, dan tergambar dalam ukuran 
yang sangat kecil untuk memudahkan penyimpanan dan penggunaan. Cetakan micro film tersebut disebut hard copy

Fungsi dan Peranan Arsip Sebagai sumber informasi, maka arsip dapat membantu meningkatkan dalam rangka pengambilan keputusan secara cepat dan tepat mengenai suatu masalah. Oleh sebab itu, dapat disimpulkan bahwa fungsi dan peranan arsip yaitu :

1. Alat utama ingatan organisasi

2. Bahan atau alat pembuktian (bukti otentik)

3. Nilai informasional yang perlu, misalnya untuk pengambilan keputusan

4. Bahan dasar perencanaan dan pengambilan keputusan

5. Nilai informasional dalam proses menuju penentuan kebijakan yang menyangkut banyak orang dan perlu memperhatikan kesinambungan serta perkembangan.

6. Barometer kegiatan suatu organisasi mengingat setiap kegiatan pada umumnya menghasilkan arsip

7. Sebagai pedoman kerja.

8. Sebagai sumber informasi yang dipergunakan baik secara lagsung atau tidak langsung dalam penyusunan perencanaan, pelaksanaan, penelitian, evaluasi dan berbangsa dan bernegara.

9. Bahan informasi kegiatan ilmiah lainnya.

Tujuan dari arsip yaitu :

- agar arsip dapat disimpan dan diketemukan kembali dengan cepat dan

- tepat, jika sewaktu-waktu diperlukan.

- dapat menunjang terlaksananya peyusutan arsip yang berdaya guna dan berhasil guna.

- Untuk menjaga arsip, agar setiap historis dari perusahaan maupun individu dapat ditempatkan disuatu tempat tertentu, dengan system penyimpanan arsip.

- Untuk mengamankan arsip yang penting, baik dari bahaya pencurian atau kebakaran.

Dalam Tata Naskah Dinas membahas tentang tata kelola surat, sehingga surat dapat di artikan sebagai alat komunikasi yang merupakan sarana penting dalam dunia bisnis, pemerintahan, pendidikan, baik perorangan maupun kelompok. Salah satu bentuk komunikasi yang sering digunakan adalah surat. Adapun beberapa pengertian surat menurut pendapat beberapa para ahli adalah :

1. Menurut Thomas Wiyasa Bratawidjaja (1982), Surat adalah alat untuk menyampaikan sesuatu maksud secara tertulis dari pihak satu kepada pihak lainnya. Surat adalah satu sarana untuk menyampaikan pernyataan atau informasi secara tertulis dari pihak satu kepada pihak lainnya.

2. Menurut Sedarmayanti (2001), Surat adalah alat komunikasi tertulis yang berasal dari satu pihak yang ditunjukkan kepada pihak lain untuk menyampaikan berita.

3. Menurut Yhundazt 1627.blogspot.com, Surat adalah suatu komunikasi yang digunakan untuk menyampaikan informasi tertulis oleh suatu pihak lain kepada pihak lainnya. Surat merupakan lembaran kertas yang tertulis atas nama pribadi penulis atau atas nama kedudukannya dalam organisasi untuk berbagai kepentingan.

4. Menurut Y. S. Marjo (2000), Surat adalah alat komunikasi tertulis atau sarana untuk menyampaikan pertanyaan maupun informasi.

5. Menurut Atmosudirjo (1999, Surat adalah kertas atau lebih yang ditulis atau diketik atas nama kedudukan dalam organisasi yang ditujukkan kepada suatu alamat tertentu dan membuat suatu badan komunikasi.

6. Menurut The Liang gie (2000), surat adalah setiap catatan tertulis atau bergambar yang memuat keterangan mengenai sesuatu hal atau peristiwa yang dibuat orang untuk membantu ingatannya.

7. Menurut Barthos (2003), Surat adalah alat komunikasi tertulis yang berasal dari satu pihak dan ditujukkan kepada pihak lain uintuk menyampaikan warta/berita.

\section{METODE}

Metode Kualitatif merupakan Metode Penelitian Naturalistik karena penelitiannya dilakukan pada kondisi yang alamiah karena data atau dokumen yang terkumpul dan analisisnya lebih bersifat kualitatif. Analisis data yang dilakukan bersifat induktif berdasarkan fakta-fakta yang ditemukan di lapangan dan kemudian dikonstruksikan menjadi hipotesis atau teori.

Metode tersebut dimaksudkan untuk mempelajari dan meneliti bagaimana cara penanganannya terhadap kearsipan sehingga kurangnya pemahaman Aparatur Sipil Negara terhadap pelaksanaan pengelolaan kearsipan yang baik.

Lokasi Penelitian berada di Sekolah Usaha Perikanan Menengah Sorong yang beralamat di Jalan Jenderal Ahmat Yani No.32 Kelurahan Klakublik Kota Sorong Provinsi Papua Barat.

Jenis dan sumber data terdiri dari data primer dan data sekunder :

- Data Primer adalah data yang di peroleh langsung dari lapangan disamping dokumen tertulis, biasanya didapatkan dari subjek penelitian dengan cara melakukan pengamatan, percobaan atau 
wawancara langsung dengan responden.

- Data Sekunder adalah data yang tidak langsung diperoleh dari sumber pertama, dan telah tersusun dalam bentuk dokumen tertulis. data-data yang digunakan adalah melalui buku-buku referensi serta Peraturan Perundang-Undangan yang ada relevansinya dengan objek yang akan dibahas,data sekunder ini akan diperoleh dengan berpedoman pada literatur-literatur sehingga dinamakan penelitian kepustakaan.

Penelitian Kepustakaan adalah penelitian yang dilakukan dengan mempelajari bahan-bahan hukum yang berkaitan dengan data sekunder yang terdiri dari :

1. Undang-Undang Nomor 05 Tahun 2014 tentang Aparatur Sipil Negara (ASN)

2. Undang-Undang Nomor 43 Tahun 2009 tentang Kearsipan

3. Peraturan Menteri Kelautan dan Perikanan Nomor :52/PERMEN-KP/2014 tentang Kearsipan lingkup Kementerian Kelautan dan Perikanan

4. Peraturan Menteri Kelautan dan Perikanan Nomor :53/PERMEN-KP/2014 tentang Pedoman Umum Tata Naskah Dinas lingkup Kementerian Kelautan dan Perikanan

5. Peraturan Kepala Badan Riset dan Sumber Daya Manusia Kelautan dan Perikanan Nomor : 7/PERBRSDM-KP/2017 tentang Petunjuk Pelaksanaan Tata Naskah Dinas lingkup Badan Riset dan Sumber Daya Manusia Kelautan dan Perikanan

6. Buku-buku Kearsipan

7. Modul-modul Kearsipan

8. Majalah-majalah Kearsipan

\section{HASIL DAN PEMBAHASAN}

Dalam rangka pelaksanaan cita-cita bangsa dalam mewujudkan tujuan negara sebagaimana tercantum dalam pembukaan Undang-Undang Dasar Negara Republik Indonesia Tahun 1945, perlu dibangun aparatur sipil negara yang memiliki integritas, profesional, netral dan bebas dari intervensi politik, bersih dari praktik korupsi, kolusi, dan nepotisme, serta mampu menyelenggarakan pelayanan publik bagi masyarakat dan mampu menjalankan peran sebagai unsur perekat persatuan dan kesatuan bangsa berdasarkan Pancasila dan Undang-Undang Dasar Negara Republik Indonesia Tahun 1945.

Untuk mewujudkan aparatur sipil negara sebagai bagian dari reformasi birokrasi, perlu ditetapkan aparatur sipil negara sebagai profesi yang memiliki kewajiban mengelola dan mengembangkan dirinya dan wajib mempertanggung jawabkan kinerjanya dan menerapkan prinsip merit atau perbandingan antara kualifikasi, kompetensi, dan kinerja yang dibutuhkan oleh jabatan dengan kualifikasi, kompetensi, dan kinerja yang dimiliki oleh calon dalam rekrutmen, pengangkatan, penempatan, dan promosi pada jabatan yang dilaksanakan secara terbuka dan kompetitif, sejalan dengan tata kelola pemerintahan yang baik dalam pelaksanaan manajemen aparatur sipil negara.

Sesuai amanat undang-undang nomor 05 tahun 2014 tentang Aparatur Sipil Negara dan undangundang nomor 43 tahun 2009 tentang Kearsipan bahwa dalam menghadapi tantangan era globalisasi dan mendukung terwujudnya penyelenggaraan negara dan khususnya pemerintahan yang baik dan bersih, serta peningkatan kualitas pelayanan publik, maka penyelenggaraan kearsipan di lembaga negara, pemerintahan, lembaga pendidikan, perusahaan, organisasi politik, organisasi kemasyarakatan dan perseorangan harus dilakukan dalam suatu sistem penyelenggaraan kearsipan nasional yang komprehensif dan terpadu.

Sehubungan dengan tantangan globalisasi saat ini, maka sudahlah perlu Aparatur Sipil Negara pada Sekolah Usaha Perikanan Menengah Sorong sudah seharusnya dan wajib hukumnya untuk menjalankan tugas sebagai abdi negara dan abdi masyarakat yang baik dan profesional dibidangnya. Baik itu dibidang administrasi maupun dibidang pendidikan.

Oleh karena itu tugas Aparatur Sipil Negara harus menjaga keamanan, ketertiban, kebersihan, keselamatan dan kerahasiaan dokumen-dokumen negara berupa kearsipan. baik itu arsip aktif maupun arsip inaktif pada lembaga pemerintah, lembaga pendidikan dll yang disebut dengan pelayanan prima. Karena sebagai pegawai pemerintahan harus royal terhadap pekerjaan yang sudah di atur dalam undangundang maupun peraturan pemerintah yang disebut Manajeman

Perkantoran yang berhubungan dengan Tata Naskah Dinas meliputi surat-surat dinas, surat non dinas serta kearsipan.

Dengan kurangnya pemahaman Aparatur Sipil Negara terhadap pengelolaan kearsipan yang baik, maka perluh diadakan pelatihan khusus agar bisa mengetahui bagai mana caranya menata, mengelola, menjaga kearsipan dengan baik karena arsip sangatlah penting bagi lembaga pemerintahan, lembaga pendidikan, organisasi dan masyarakat maupun individu. Yang kita ketahuai arsip itu bukan hanya terdapat di sebuah kantor pemerintahan saja namun juga terdapat di rumah dan dimana saja, oleh sebab itu kita harus mengetahui maksud, arti, fungsi dan tujuan dari kearsipan. karena arsip itu sebagai 
alat bukti yang sah buat diri kita sendiri maupun buat orang lain yang membutuhkan, sehingga kita harus mengelola dengan baik. Karena dalam tugas dan fungsi Aparatur Sipil Negara sudah jelas pada unit pengelola atau unit pelaksana tugas masing-masing.

Adapun unit pengelola dalam arti kearsipan adalah satuan kerja pada pencipta arsip yang mempunyai tugas dan tanggungjawab mengolah semua arsip yang berkaitan dengan kegiatan penciptaan arsip dilingkungannya. Sedangkan unit kearsipan adalah satuan kerja pada pencipta arsip yang mempunyai tugas dan tanggungjawab dalam penyelenggaraan kearsipan.

Ketentuan umum dalam undang-undang yang dimaksud dengan kearsipan adalah hal-hal yang berkenang dengan arsip baik itu arsip aktif maupun arsip inaktif.

- Arsip adalah rekaman kegiatan atau peristiwa dalam berbagai bentuk dan media sesuai dengan perkembangan teknologi informasi dan komunikasi yang dibuat dan diterima oleh lembaga negara, pemerintahan, lembaga pendidikan, perusahaan, organisasi politik, organisasi kemasyarakatan dan perseorangan dalam pelaksanaan kehidupan bermasyarakat, berbangsa dan bernegara

- Arsip aktif adalah arsip yang frekuensi penggunaannya tinggi dan/atau terus menerus

- Arsip inaktif adalah arsip yang frekuensi penggunaannya telah menurun

- Penyelenggaraan kearsipan adalah keseluruhan kegiatan meliputi kebijakan, pembinaan kearsipan, dan pengelolaan arsip dalam suatu sistem kearsipan nasional yang didukung oleh sumber daya manusia, prasarana dan sarana serta sumber daya lainnya

a. Maksud dan tujuan kearsipan adalah sebagai beriku :

- Untuk memberikan kepastian hukum dalam penyelenggaraan kearsipan nasional

b. Penyelenggaraan kearsipan bertujuan untuk :

- Menjamin terciptanya arsip dari kegiatan yang dilakukan oleh lembaga negara, pemerintahan, lembaga pendidikan, perusahaan, organisasi politik, organisasi kemasyarakatan dan perseorangan serta Arsip Nasional Republik Indonesia sebagai penyelenggaraa kearsipan nasional

- Menjami8n ketersedianya arsip yang autentik dan terpercaya sebagai alat bukti yang sah

- Menjamin terwujudnya pengelolaan arsip yang andal dan pemanfaatan arsip sesuai dengan ketentuan peraturan perundang-undangan
- Menjamin perlindungan kepentingan negara dan hak-hak keperdataan rakyat melalui pengelolaan dan pemanfaatan arsip yang autentik dan terpercaya.

- Mendinamiskan penyelenggaraan kearsipan nasional sebagai suatu sistem yang komperhensip dan terpadu

- Menjamin keselamatan dan keamanan arsip sebagai bukti pertanggung jawaban dalam kehidupan bermasyarakat, berbangsa dan bernegara

- Menjamin keselamatan aset nasional dalam bidang ekonomi, sosial, politik, budaya, pertahanan serta keamanan sebagai identitas dan jati diri bangsa

- Meningkatkan kualitas pelayanan publik dalam pengelolan dan pemanfaatan arip yang autentik dan terpercaya.

Penyelenggaraan kearsipan di laksanakan berasaskan : kepastian hukum, keautentikan, keterpercayaan, keutuhan, asal usul, keamanan, keselamatan, keprofesionalan, keantisipatifan, kepartisipatifan, akuntabilitas, kemanfaatan, aksesibilitas dan kepentingan umum.

Penyelenggaraan kearsipan untuk mempertinggi mutu penyelenggaraan kearsipan nasional melakukan penelitian dan pengembangan serta penyelenggaraan pendidikan dan pelatihan kearsipan.

Untuk pola penanganan arsip terdiri dari penangan arsip pola sentralisasi dan penanganan arsip pola desentralisasi :

1. Pola sentralisasi adalah pola penanganan arsip terpusat yaitu tempat penanganan dan penyimpanan arsip pada satu bagian, biasanya bagian itu disebut tata usaha atau sekretariat. Ciri dari pola ini dalam penanganan arsip adalah dengan digunakannya kartu kendali, kartu kendali ini terdiri atas 3 lembar yang yang akan dipegang oleh arsiparis, kepala sub bagian tata usaha dan sekretaris/bagian yang mempunyai arsip. Kegunaan dari kartu kendali ini untuk memudahkan pencarian dari masing-masing bagian yang mempunyai arsip tersebut untuk ditemukan oleh arsiparis

2. Pola desentralisasi adalah suatu pola penanganan arsip yang dilakukan oleh masing-masing bagian yang mempunyai arsip, baik itu penyusunan dan penyimpanannya. Ciri dari pola ini adalah setiap bagian akan mempunyai tempat penyimpanan arsip sendiri.

Berdasarkan fungsi arsip dapat digolongkan menjadi dua yaitu arsip dinamis dan arsip statis yaitu : 
- Arsip dinamis yaitu arsip yang masih di perlukan secara langsung dalam perencanaan, pelaksanaan, penyelenggaraan kehidupan kebangsaan pada umumnya, atau arsip yang digunakan secara langsung dalam penyelenggaraan administrasi negara. Adapun arsip dinamis terbagia tas dua yakni :

- Arsip dinamis aktif (active file) adalah arsip yang menyimpan surat-surat yang masih berada dalam proses penyelesaiannya, surat-surat dalam arsip aktif ini asli dikeluarkan untuk kepentingan tertentu

- Arsip dinamis inaktif (in active file) adalah arsip yang menyimpan surat-surat yang jarang dipergunakan karena sudah selesai dalam prosesnya, tetapi kadang-kadang masih diperlukan, dalam penyimpanan ini sering pula dimaksudkan untuk menunggu saat-saat pemusnahan bagi surat-surat yang tidak berlaku lagi

- Arsip statis yaitu arsip yang tidak dipergunakan secara langsung untuk perencanaan pelaksanaan penyelenggaraan kehidupan kebangsaan pada umumnya, maupun untuk penyelenggaraan administasi sehari-hari. Arsip statis merupakan arsip yang menyimpan surat-surat vital yang akan disimpan selama-lamanya. Pemusnahan arsiparsip instansi pemerintahan dilakukan oleh arsip Nasional, oleh karena itu setiap instansi berkewajiban untuk memisahkan surat-surat antara surat-surat yang dapat dimusnahkan dan yang perlu disimpan selama-lamanya.

Yang dimaksud dengan kearsipan adalah suatu proses penyimpanan arsip secara sistematis agar mudah ditemukan kembali, yang meliputi penciptaan (pembuatan dan penerimaan), penyimpanan (filing) dan penemuan kembali (finding), penyelamatan (pengamanan, pemeliharaan dan perawatan) dan penyusutan arsip (pemindahan, penyerahan dan pemusnahan).

Tujuan kegiatan kearsipan adalah untuk menyimpan surat-surat sedemikian rupa sehingga mudah ditemukan kembali sewaktu-waktu diperlukan.

Peralatan yang digunakan dalam sistem kearsipan di SUPM Sorong berupa penyimpanan dan penemuan kembali arsip adalah

1. Filing cabinet adalah lemari arsip terdiri dari lacilaci yang digunakan untuk menyimpan dokumen atau surat yang telah menjadi arsip

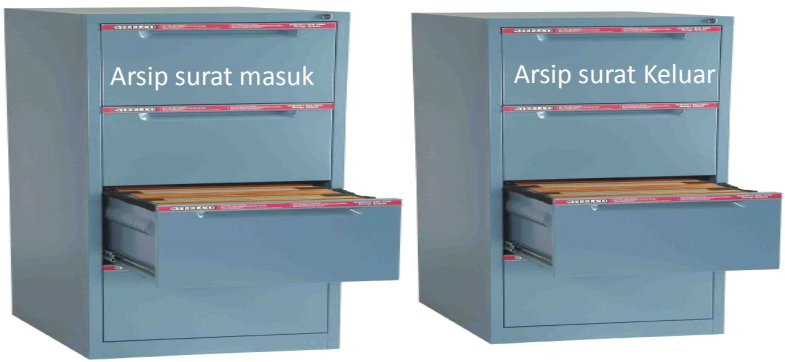

Sumber : Tata Usaha SUPM Sorong

Gambar 1. Filing cabinet surat masuk dan surat keluar
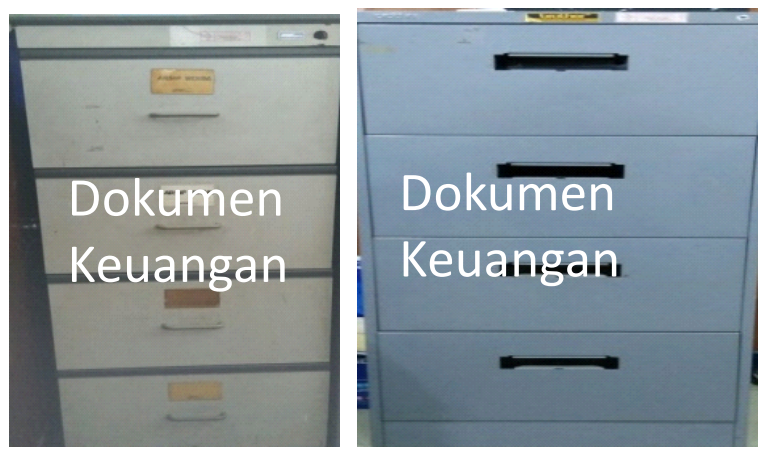

Sumber : Keuangan SUPM Sorong

\section{Gambar 2. Filing cabinet arsip keuangan}

2. Guide adalah pembatas untuk memisahkan arsip berdasarkan jenisnya, sesuai sistem penyimpanan arsip yang digunakan. Biasanya guide ini dilengkapi dengan tab untuk mencantumkan pokok masalah.

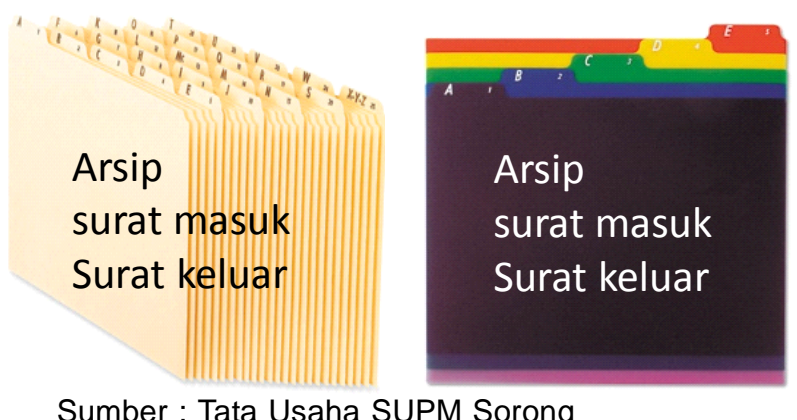

Gambar 3. Guide untuk surat masuk dan surat keluar

3. Map gantung / hanging folder adalah suatu tempat atau folder yang digunakan untuk menyimpan dokumen arsip, biasanya apabila kita menyimpan arsip dalam lemari arsip atau filing cabinet dapat menggunakan hanging folder atau map gantung. 


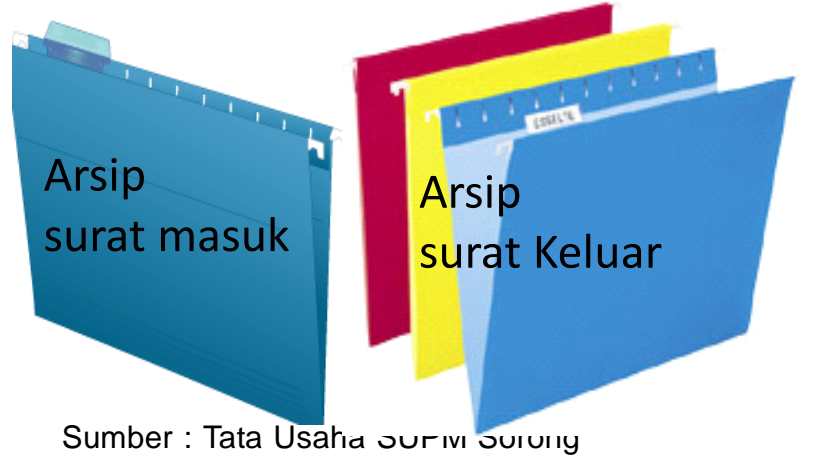

Gambar 4. Map gantung surat masuk dan surat keluar

4. Ordner adalah map untuk menyimpan dokumen arsip, apabila menggunakan di tempat penyimpanan kronologis atau wilayah, bagian dalam ordner dilengkapi dengan besi untuk mengikat arsip yang yang telah diberi lubang sebelumnya.
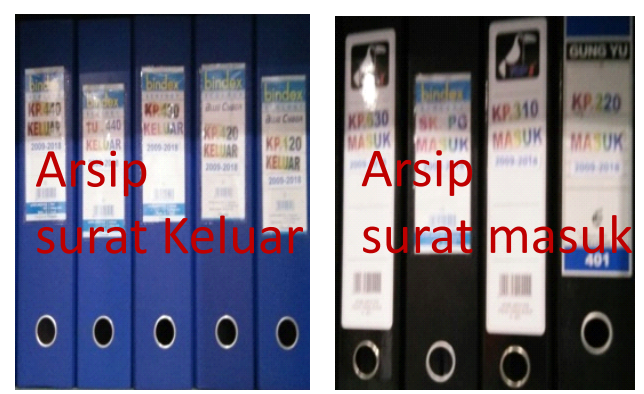

Sumber : Tata Usaha SUPM Sorong

Gambar 5. Ordner arsip surat masuk dan surat keluar

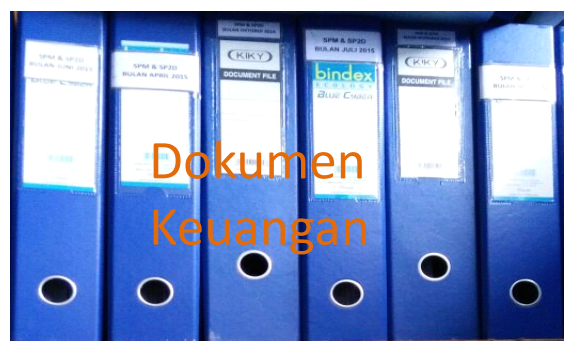

Sumber : Keuangan SUPM Sorong

\section{Gambar 5. Ordner Dokumen Keuangan}

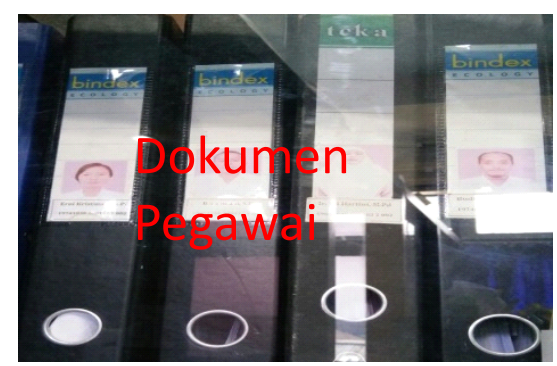

Sumber : Kepegawaian SUPM Sorong Gambar 6. Ordner dokumen kepegawaian

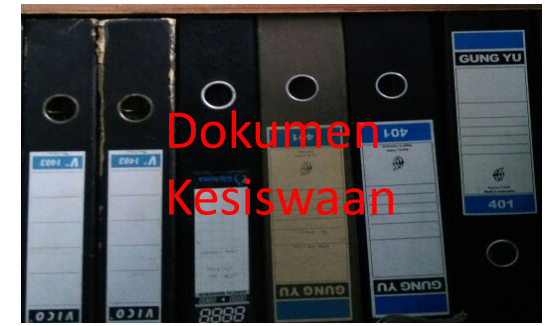

Sumber : Kesiswaan SUPM Sorong

Gambar 7. Ordner Dokumen Kesiswaan

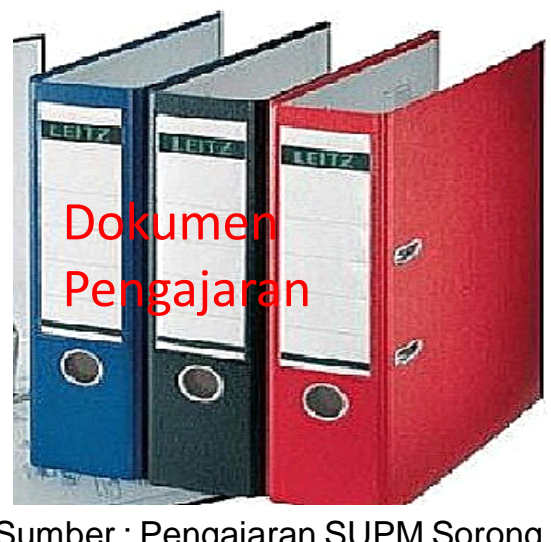

Gambar 8. Ordner Dokumen Pengajaran

5. Komputer adalah alat untuk menyimpan dan mengelola arsip dalam bentuk digital

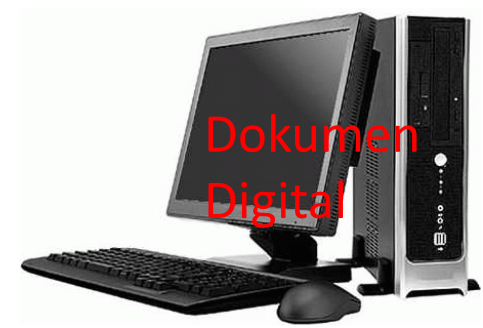

Sumber : Tata Usaha SUPM Sorong

Gambar 9. Komputer mengelola arsip digital

6. Scanner adalah alat untuk memindai dokumen yang akan disimpan secara digital

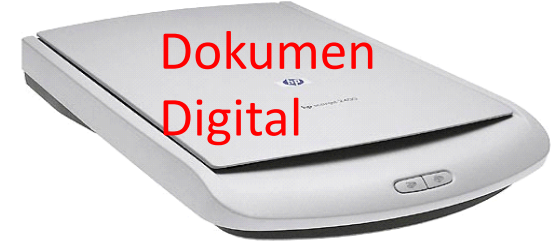

Sumber : Tata Usaha SUPM Sorong

Gambar 10. Scanner memindai dokumen yang disimpan secara digital 
7. Buku agenda surat masuk dan surat keluar adalah buku yang dipergunakan untuk mencatat surat masuk dan surat keluar, berfungsi sebagai pedoman dalam penyimpanan arsip atau dokumen.

\begin{tabular}{|c|c|c|c|c|c|c|c|c|}
\hline \multirow[t]{2}{*}{ No } & \multirow{2}{*}{$\begin{array}{l}\text { Kede } \\
\text { Suser: }\end{array}$} & \multicolumn{2}{|c|}{$\begin{array}{l}\text { Nomee } 8 \text { sy } \\
\text { suret }\end{array}$} & \multirow{2}{*}{$\begin{array}{l}\text { yn: } \\
\text { yox }\end{array}$} & \multirow{2}{*}{ ren } & \multirow[t]{2}{*}{$d m$} & \multirow{2}{*}{ Kes. } & \multirow[t]{2}{*}{$\mathrm{ke}$} \\
\hline & & No & $T$ & & & & & \\
\hline & & & & & & & & \\
\hline & & & & & & & & \\
\hline & & & & & & & & \\
\hline & & & & & & & & \\
\hline
\end{tabular}

\begin{tabular}{|c|c|c|c|c|c|c|c|c|c|}
\hline \multirow{2}{*}{$\begin{array}{l}\mathrm{N} \\
\mathrm{O}\end{array}$} & \multirow[t]{2}{*}{$\mathrm{T}$} & \multicolumn{2}{|c|}{$\begin{array}{l}\text { Nomor \& tgl } \\
\text { Surat masuk }\end{array}$} & \multirow{2}{*}{$\begin{array}{l}\text { Sifat } \\
\text { Surat }\end{array}$} & \multirow{2}{*}{$\begin{array}{l}\text { Peri } \\
\text { hal }\end{array}$} & \multirow[t]{2}{*}{ dari } & \multirow{2}{*}{$\begin{array}{l}\text { Ke } \\
\text { pad } \\
\text { a }\end{array}$} & \multirow{2}{*}{$\begin{array}{l}\text { Pengola } \\
\mathrm{h}\end{array}$} & \multirow{2}{*}{$\begin{array}{l}\text { Ko } \\
\text { de } \\
\text { arsi } \\
\text { pi }\end{array}$} \\
\hline & & $\begin{array}{l}\begin{array}{l}\text { No } \\
\text { bks }\end{array} \\
\end{array}$ & Tgl & & & & & & \\
\hline & & & & & & & & & \\
\hline & & & & & & & & & \\
\hline & & & & & & & & & \\
\hline & & & & & & & & & \\
\hline & & & & & & & & & \\
\hline & & & & & & & & & \\
\hline & & & & & & & & & \\
\hline
\end{tabular}

Sumber : Tata Usaha SUPM Sorong

\section{Gambar 11. Buku agenda surat keluar dan surat masuk}

Penyelenggaraan arsip yang baik tidak hanya ditentukan oleh peralatannya yang serba canggih, dan pemilihan sistem penyimpanannya yang tepat saja.Tetapi yang lebih penting lagi adalah pengelolaan arsip itu sendiri. Sebab tiap orang mempunyai bakat dan kemampuan yang berbeda. Misalnya ada orang yang mempunyai bakat dan kemampuan untuk bekerja pada bagian keuangan tetapi tidak pada bagian public relation, ada orang yang memiliki bakat dan kemampuan di bidang pemasaran, tetapi tidak berbakat di bidang produksi atau sebaliknya. Itulah sebabnya tidak semua orang yang berbakat di bidang produksi atau sebaliknya. Itulah sebabnya tidak semua orang yang berbakat dan memiliki kemampuan dan keterampilan untuk mengelola arsip dengan baik.

Seorang pegawai dinyatakan terampil apabila ia dapat bekerja sesuai dengan standar yang diharapkan. Artinya dapat bekerja sesuai mutu, jumlah dan waktu yang telah ditetaplan, apablia pegawai dapat berkerja melebihi standar adalah pegawai yang amat terampil, sebaliknya apabila tidak dapat memenuhi standar, maka pegawai tersebut dianggap tidak terampil.

Keterampilan yang harus dimilik oleh seorang pegawai administrasi adalah :
a. Terampil menggunakan macam-macam sistem filling
b. Terampil memilih dan menyeleksi surat

c. Terampil menyimpan berbagai macam surat/arsip

d. Terampil menemukan kembali arsip yang dibutuhkan

e. Terampil menggunakan perlatan yang dipergunakan dalam kearsipan

f. Terampil mengetik berbagai surat maupun kartu/ formulir yang dipakai

g. Terampil menggunakan alat bantu kearsipan lainnya

Sehubungan dengan kurangnya pemahaman aparatur sipil negara dalam mengolah arsip dengan baik pada unit pelaksana teknis, baik itu dibidang adminitrasi maupun dibidang teknis agar perluh diikut sertakan dalam pengembangan diri dalam bidang kearsipan (pelatihan kearsipan), agar bisa menambah ilmu untuk dapat menata, menjaga, merawat, melindungi arsip dengan baik agar mengasilkan arsip itu sebagai alat bukti yang sah dan sebagai jati diri bangsa.

\section{KESIMPULAN}

Dilihat dari pokok permasalahan diatas maka dapat disimpulkan bahwa :

1. Pada dasarnya aturan sudah dibuat dengan jelas dan benar yakni menurut undang-undang nomor 5 tahun 2014 tentang Aparatur Sipil Negara dan undang-undang nomor 34 tahun 2009 tentang Kearsipan yang menjelaskan bahwa dalam menghadapi tantangan era globalisasi dan mendukung terwujudnya penyelenggaraan negara dan khususnya pemerintahan yang baik dan bersih, serta peningkatan kualitas pelayanan publik, maka penyelenggaraan kearsipan di lembaga negara, pemerintahan, lembaga pendidikan, perusahaan, organisasi politik, organisasi kemasyarakatan dan perseorangan harus dilakukan dalam suatu sistem penyelenggaraan kearsipan nasional yang komprehensif dan terpadu.

2. Tugas Aparatur Sipil Negara harus menjaga keamanan, ketertiban, kebersihan, keselamatan dan kerahasiaan dokumen-dokumen negara berupa kearsipan. baik itu arsip aktif maupun arsip inaktif pada lembaga pemerintah, lembaga pendidikan dll yang disebut dengan pelayanan prima. Karena sebagai pegawai pemerintahan harus royal terhadap pekerjaan yang sudah di atur dalam undang-undang maupun peraturan pemerintah yang disebut Manajeman Perkantoran yang berhubungan dengan Tata Naskah Dinas meliputi surat-surat dinas, surat non dinas serta kearsipan.

3. Sekolah Usaha Perikanan Menengah Sorong di bawah naungan Kementerian Kelautan dan Perikanan dan lingkup Badan Riset dan Sumber Daya Manusia Kelautan dan Perikanan, maka 
Kearsipan dan Tata Naskah Dinas berpedoman pada Peraturan Menteri Kelautan dan Perikanan Nomor : 53/PERMEN-KP/2014 tentang Kearsipan dan Peraturan Menteri Kelautan dan Perikanan Nomor : 52/PERMEN-KP/2014 tentang Pedoman Umum Tata Naskah Dinas serta Peraturan Kepala Badan Riset dan Sumber Daya Manusia Kelautan dan Perikanan Nomor : 7/PER-BRSDM-KP/2017 tentang Petunjuk Pelaksanaan Tata Naskah Dinas lingkup Badan Riset dan Sumber Daya Manusia Kelautan dan Perikanan

4. Aparatur Sipil Negara pada SUPM Sorong seharusnya telah memahami tugas dan fungsi serta Standar Operasioanal Prosedur (SOP) yang ada di SUPM Sorong saat ini, namun pada dasarnya pegawai sendiri yang kurang royal terhadap kearsipan sehingga arsip pada ruangan masing-masing tidak tertatah dengan baik dan benar pada tempatnya, karena menurut pemahaman pegawai bahwa itu hanya kertas dan tidak ada makna apapun sehingga tidak perlu diurus.

5. Kurangnya pemahaman Aparatur Sipil Negara juga mungkin karena minimnya Sumber Daya Manusia maupun Sumber Dananya untuk mengelola ruangan arsip maupun ruangan dokumen-dokumen lainnya

\section{SARAN}

Dari kesimpulan pembahasan jurnal ini maka dapat disarankan bahwa :

1. Aparatur Sipil Negara perlu dibekali dengan ilmuilmu yang mendasar sehingga didalam menjalankan tugas sebagai abdi negara dan abdi masyarakat dapat berjalan sesuai aturan yang berlaku.

2. Aparatur Sipil Negara pada SUPM Sorong perlu diberi pelatihan khusus dibidang administrasi, karena pegawai administrasi banyak berhubungan dengan namanya surat-menyurat, kearsipan maupun arsip dll, karena pada umumnya pegawai belum mengerti apa itu administrasi apalagi kearsipan yang kita tahu arsip itu sebagai alat bukti yang sah dan sebagai jati diri bangsa.

3. Perlu adanya ruangan kearsipan yang memadai biar arsip tertahtah dengan baik, sehingga tidak ada arsip yang tercecer kemana-mana.

\section{DAFTAR PUSTAKA}

Abubakar, Radi. 1997. Cara-cara Pengelolaan Kearsipan yang Praktis dan Efisien, Jakarta

Drs. Ig. Wursanto, Maulana, 1974, Kearsipan adalah suatu metode atau cara yang direncanakan dan dipergunakan untuk menyimpan, pemeliharaan arsip bagi individu maupun umum dengan memakai indeks yang sudah ditentukan

Martono, Boedi. 1994. Peanataan Berkas dalam Manajemen Kearsipan. Jakarta. Sinar Harapan

Muhsin, dan Marimin, 1985, kearsipan yaitu tata cara pengurusan penyimpanan warkat menurut aturan dan procedure yang berlaku dengan mengingat 3 unsur pokok yang meliputi : penyimpanan, penempatan, dan penemuan kembali

Peraturan Menteri Kelautan dan Perikanan Nomor : 52/PERMEN-KP/2014 tentang Kearsipan lingkup Kementerian Kelautan dan Perikanan

Peraturan Menteri Kelautan dan Perikanan Nomor : 53/PERMEN-KP/2014 tentang Pedoman Umum Tata Naskah Dinas lingkup Kementerian Kelautan dan Perikanan.

Peraturan Kepala Badan Riset dan Sumber Daya Manusia Kelautan dan Perikanan Nomor : 7/PERBRSDM-KP/2017 tentang Petunjuk Pelaksanaan Tata Naskah Dinas lingkup Badan Riset dan Sumber Daya Manusia Kelautan dan Perikanan.

Sulistyo Basuki, 2003, Manajemen Arsip Dinamis: Pengantar Memahami dan Mengelolah Informasi dan Dokumen. Jakarta : PT. Gramedia Pustaka Utama,

The Liang Gie, 2000, Arsip sebagai kumpulan warkatwarkat yang disimpan secara teratur, berencana karena mempunyai sesuatu kegunaan agar setiap kali diperlukan dapat cepat ditemukan kembali

Undang-Undang Dasar Negara Republik Indonesia Tahun 1945.

Undang-Undang Nomor 5 Tahun 2014 tentang Aparatur Sipil Negara (ASN)

Undang-Undang Nomor 43 Tahun 2009 tentang Kearsipan.

Wursanti, 1991. "Arsip adalah kumpulan warkat yang disimpan secara teratur berencana karena mempunyai suatu kegunaan agar setiap kali diperlukan dapat cepat ditemukan kembali”.

Zulkifli amsyah 1996, Manajemen Kearsipan. Jakarat :PT. Gramedia Pustaka Utama 


\section{Lampiran. PROFIL KEADAAN RUANGAN KERJA DAN TEMPAT ARSIP DI SUPM SORONG}
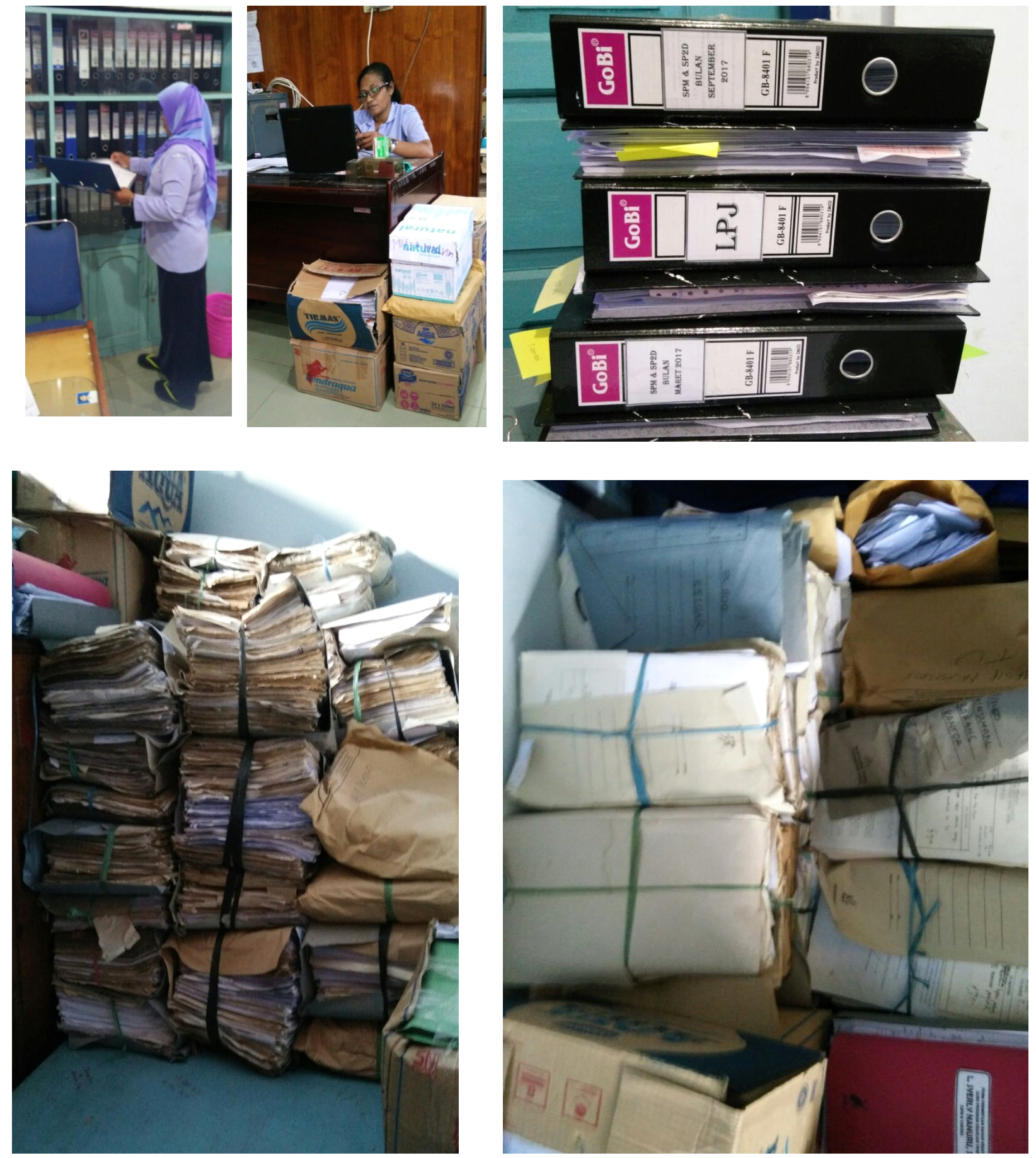

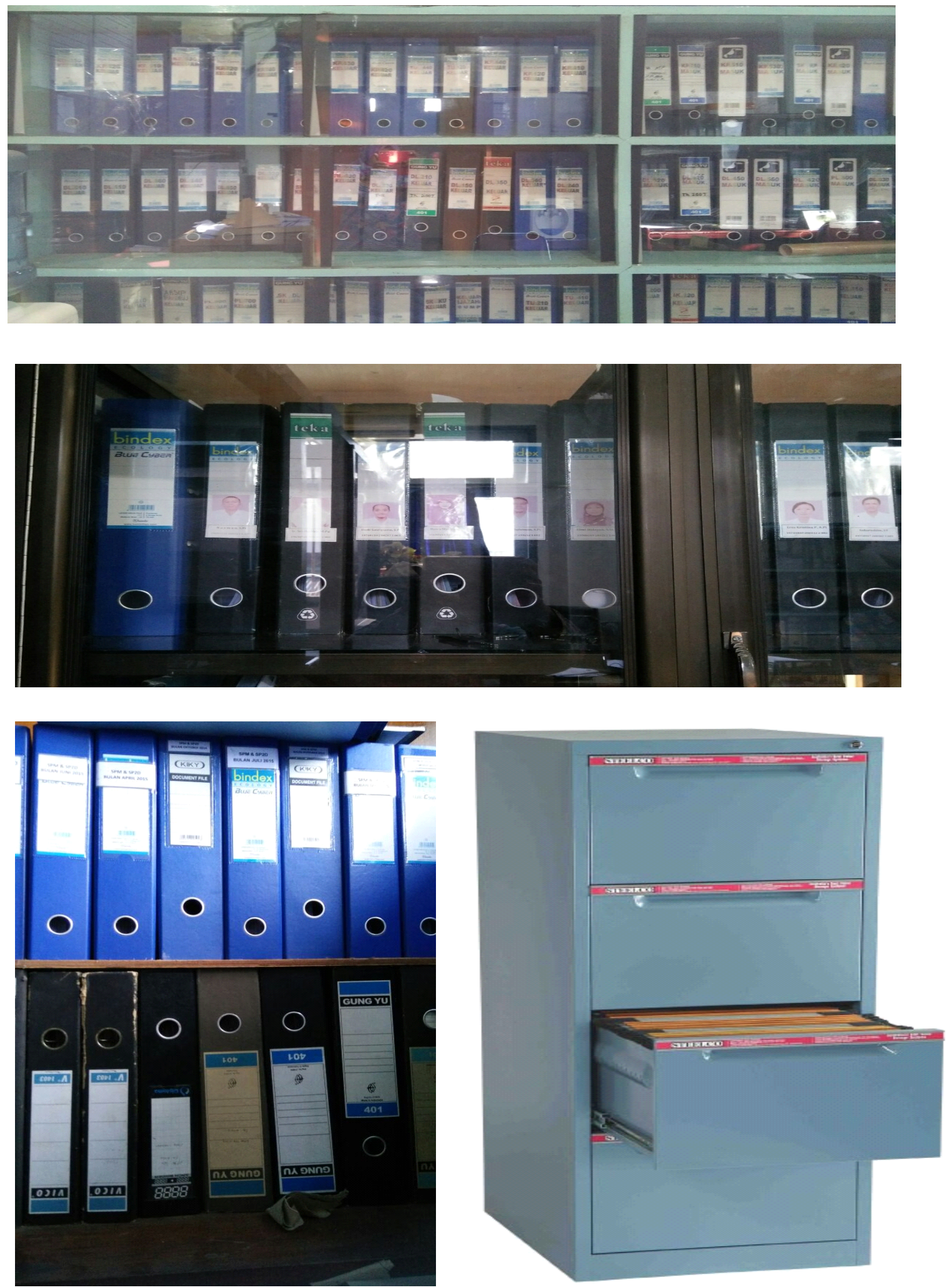